\title{
A Study on How to Utilize Waste Paper and Coffee Residue for Briquettes Production
}

\author{
P. Patcharee and T. Naruephat
}

\begin{abstract}
Some residues from industries and households were used to turn into briquettes. In this research, waste paper and coffee residues could be practically used to produce fuel briquettes by adding starch as a binder before performing a molding cold process. The optimal ratios between waste paper and coffee residue were considered to be 70:30, 60:40, 50:50, 40:60, and 30:70. Their calorific values ranged from 3,708.5 to 4,347.1 cal/g. These values were almost equivalent to the amount of the heat from the firewood. The study also discovered that the briquettes rendered their moisture content (7-9\%), the amount of ash (3.8-8.5\%), and the amounts of fuel elements $(45.56 \%$ carbon, $6.48 \%$ hydrogen, $45.41 \%$ oxygen, $0.75 \%$ nitrogen, and $0.08 \%$ sulfur) within the acceptable values of biomass standards. The briquettes were readily molded, not easily shattered, and inflammable with low amount of smoke and odor. Therefore, the production of fuel briquettes from waste paper and coffee residue could be one of the viable alternatives for community energy generation.
\end{abstract}

Index Terms - Coffee residue, fuel briquettes, waste paper.

\section{INTRODUCTION}

In Thailand, both plants and animals such as wood, firewood, rice hulls, sugarcane, corncobs, corn plants, dung (e.g. cow dung, pig dung), and wastes from agricultural processing plants and rubbish (e.g. garbage, sawdust)can be used as biomass energy sources. As people in the rural areas still rely on firewood and wood charcoal to cook and boil their food, deforestation occurs in many parts of the country. However, green fuels have been recently used to replace firewood and wood charcoal. Therefore, making use of those waste materials could be a viable alternative for future energy production. Since it would reduce the consumption of firewood and wood charcoal, it could be one of the solutions that help conserve forest resources.

Various forms of paper and its products have played a significant role in our daily lives (e.g. packaging materials in manufactures, educational activities, office works.) In Thailand, paper has been used approximately $34 \mathrm{~kg}$ per person per year, or 2 million tons per year with the annually increasing rate of $15 \%$ [1]. In addition, making use of waste paper would benefit people more than just discarding it and help the government reduce community waste management cost.

Coffee crops have been one of the agricultural products traded most in the world. In 2001, from 67.01 million hectares of meat, there were approximately 7.01 million tons of coffee crops generated in the world. With the amount of 1.78 million tons of coffee crops $(1,244 \mathrm{~kg} /$ hectare $)$ from

Manuscript received May 10, 2014; revised July 10, 2014.

P. Patcharee and T. Naruephat are with the Srinakharinwirot University (e-mail: patchareep@g.swu.ac.th, aruephat@g.swu.ac.th).
4.39 million hectares of land, Brazil is the world's major producer, followed by Vietnam, while Thailand contributed 1.12 percent to the global output [2] (Source: Thailand, Office of agricultural Economics, other countries, Food and Agriculture Organization of the United Nations).In 2002, 456,338acres of planted areas (from 416,096farms) were used in Thailand, producingapproximately59,537 tons of coffee crops. (Source : Department of Agriculture. Group Strategy and Technology). Table I show that in 2006-2008 the higher volumes of coffee crop production from the world's major countries were a result of an increase of coffee consumption in the world population. Hence, there was a substantial rise in the amount of coffee residue generated from industrial sites and coffee shops, see Fig. 1.

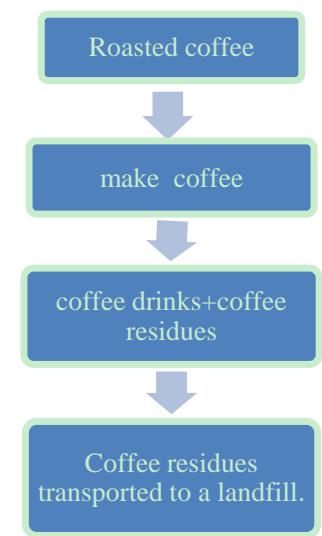

Fig. 1. The mechanism of roasted coffee products.

TABLE I: THE AMOUNTS OF COFFEE CROPS PRODUCED IN WORLD'S MAJOR COUNTRIES, 2006-2008

\begin{tabular}{cccc}
\hline \hline & \multicolumn{3}{c}{ Production (1,000 tons) } \\
\cline { 2 - 4 } Country & Year 2006 & Year 2007 & Year 2008 \\
\hline World Total & 7,995 & 7,849 & 8,235 \\
Brazil & 2,573 & 2,249 & 2,791 \\
Vietnam & 985 & 916 & 1,056 \\
Columbia & 725 & 757 & 689 \\
Indonesia & 682 & 676 & 683 \\
Ethiopia & 241 & 326 & 273 \\
Mexico & 280 & 269 & 266 \\
India & 274 & 288 & 262 \\
Guatemala & 221 & 252 & 255 \\
Peru & 273 & 226 & 226 \\
Honduras & 199 & 218 & 218 \\
Thailand & 47 & 56 & 50 \\
Others & 1,494 & 1,617 & 1,467 \\
\hline \hline
\end{tabular}

Source: Food and Agriculture Organization of the United Nations $1 /$ Update by Office of Agricultural Economics Remark: Thailand is ranked No. 20 in the world

In this study, we aimed to turn waste paper and coffee residues (from industries and households) into briquettes. These briquettes have a potential to release sufficient level of heating value to become a good alternative for Liquid 
Petroleum Gas (LPG) substitution. The briquettes would also help reduce the waste burden of the communities and the energy allocation from other countries.

\section{METHOD AND MATERIAL}

Firstly, paper (brought from several offices) was cut into small pieces. Then the pieces were drenched with water for one night and put into a grinder before having water removed. Secondly, the coffee residue (from a beverage container) was placed under the sun or put into an oven (at approximately $\left.105^{\circ} \mathrm{C}\right)$. The residue and the paper were mixed in optimal ratios (waste paper : coffee residue $=70: 30,60: 40,50: 50$, $40: 60$, and $30: 70$ ) with prepared flour at desired proportions. Subsequently, the mixture was compressed and molded into pieces $(5 \mathrm{~cm}$ diameter and $3 \mathrm{~cm}$ deep each). Then, the pieces were put under the sun for a couple of hours as shown in Fig. 2.

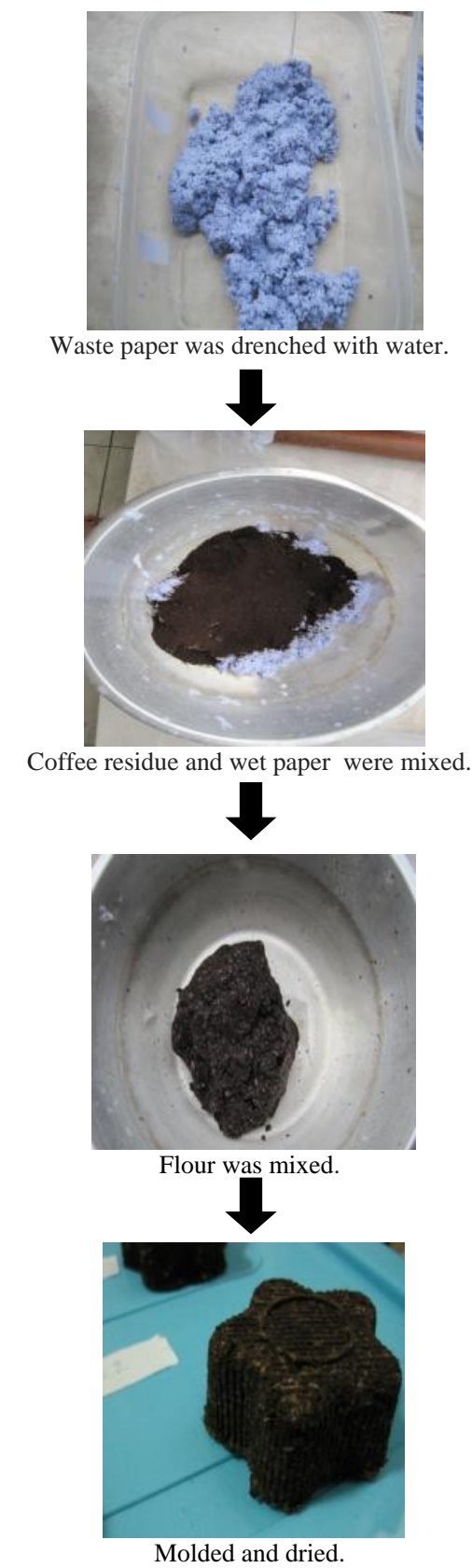

Fig. 2. The process of producing fuel briquette from waste paper and coffee residue.

\section{ANALYTICAL INSTRUMENTS}

The dried fuel briquettes were analyzed on their physical properties based on ASTM standard.

\section{A. Calorific Values}

The calorific values were measured by Bomb Calorie meter (LECO, Model AC-350). Heat value or calorific value determines the energy content of a fuel which depends on biomass's chemical composition and moisture content.

\section{B. Percentage Moisture Content (PMC)}

The moisture percentages were measured by Moisture Analysis (SATORIUS, ModelMAT50). The percentage moisture content was found by oven drying the briquette sample at $105^{\circ} \mathrm{C}$ until the mass of sample was constant. The Equation 1 was then used ( $\mathrm{E}=$ briquette sample's weight, $\mathrm{D}=$ weight loss)

$$
P M C_{(d b)}=\frac{D}{E} \times 100
$$

\section{Percentage Ash Content (PAC), Percentage Volatile} Matter (PVM) and Percentage Fixed Carbon (PFC)

Ash percentages (measured by ASTM D4809-06) using Equation 2, volatile percentages (ASTM D3172-85) using Equation 3 and the amounts of fixed carbon (ASTM D3172-85)using Equation 4 were all analyzed under ASTM standards.

$$
\begin{gathered}
P A C=\frac{C}{A} \times 100 \\
P V M=\frac{A-B}{A} \times 100 \\
\text { Fixed carbon }=100 \%-(P A C+P M C+P V M))
\end{gathered}
$$

\section{Ultimate Analysis}

The amounts of carbon, hydrogen, nitrogen, oxygen, and sulfur (under Ultimate Analysis) were estimated by Elemental Analyzer (EA) (CHNS / O Analyzer), Perkin Elmer, model PE 2400 series II), X-Ray Fluorescence Spectrometer (XRF), and Wavelength Dispersive(Phillips, modelPW2400).

\section{RESUlt AND Discussion}

\section{A. The Analysis of the Amount of Binder Used and the Molding of a Fuel Briquette}

A set of three tests was conducted to determine if a briquette had sufficient structural integrity to hold together(The Legacy Foundation 2003): the Squeeze Test, the Expansion Test, and the Shake Test [2].

Dried coffee residue collected from a coffee cup was crumbling and not stuck together, but after being mixed with slightly damp waste paper (high adhesive by nature), the residue (aided by starch used as a paste adhesive)was blended well with the paper. The higher amount of the coffee residue, the more the starch used to bind them together (ranging from $0.57 \%-7.47 \%$ ). In case of making a briquette from waste paper alone, the paper was hold together fairly well, but it was quite difficult to mold the paper that way. It was also problematic to remove the paper from a molder as the paper 
needed to remain in the molder until it was dried out. However, the mixture of waste paper and coffee residue enabled a molding process to be conducted more easily, which also depended on the amount of the residue added in the mixture. However, when the coffee residue was added in the mixture to the level of $90-100 \%$ of its total weight, the briquette became slightly cracked. Fuel briquettes produced from the mixture of waste paper and coffee residue was inflammable with low amount of smoke. The optimal ratios between waste paper and coffee reside were 70:30, 60:40, 50:50, 40:60 and 30:70.

TABLE II: THE RESUlT OF THREE TESTS VARIED BY RATIO OF WASTE

\begin{tabular}{cc} 
PAPER : COFFEE RESIDUE \\
\hline $\begin{array}{c}\text { Ratio } \\
\text { (waste paper : coffee } \\
\text { residue) }\end{array}$ & A set of three tests \\
\hline $100: 0$ & Barely malleable \\
$80: 20$ & Easily molded \\
$70: 30$ & Easily molded \\
$60: 40$ & Easily molded \\
$50: 50$ & Easily molded \\
$40: 60$ & Easily molded \\
$30: 70$ & Easily molded \\
$20: 80$ & Malleable \\
$0: 100$ & Malleable \\
\hline \hline
\end{tabular}

TABLE III: THE PHYSICAL PROPERTIES OF THE FUEL BRIQUETTE BASED ON THE RATIOS OF WASTE PAPER AND COFFEE RESIDUE

\begin{tabular}{|c|c|c|}
\hline $\begin{array}{c}\text { Ratio } \\
\text { (waste paper : coffee } \\
\text { residue) }\end{array}$ & $\begin{array}{l}\text { Calorific values } \\
\text { (cal/g) }\end{array}$ & $\begin{array}{c}\text { Moisture } \\
\text { content }(\%)\end{array}$ \\
\hline $100: 0$ & 3230.7 & 6.67 \\
\hline $80: 20$ & 3504.4 & 7.14 \\
\hline $70: 30$ & 3708.5 & 7.45 \\
\hline $60: 40$ & 3945.4 & 7.76 \\
\hline $50: 50$ & 4019.4 & 8.02 \\
\hline $40: 60$ & 4219.3 & 9.01 \\
\hline $30: 70$ & 4347.1 & 9.17 \\
\hline $20: 80$ & 4598.1 & 9.68 \\
\hline $0: 100$ & 4845.9 & 10.85 \\
\hline
\end{tabular}

B. The Analysis of the Calorific Values and the Moisture Contents of the Fuel Briquettes

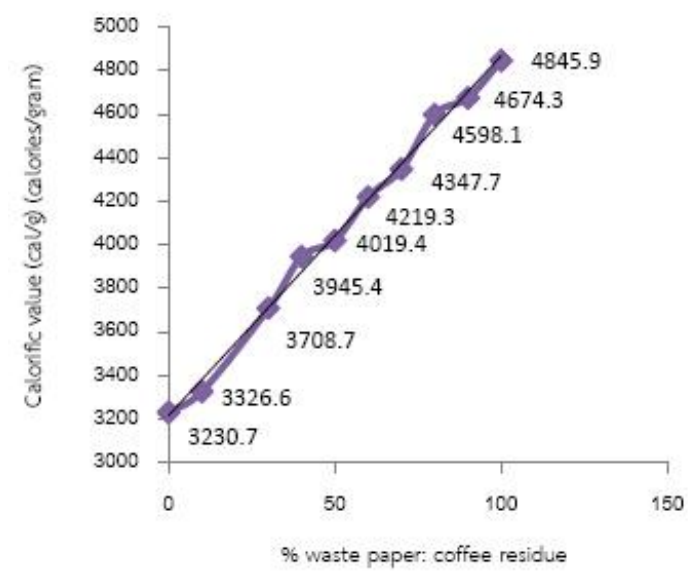

Fig. 3. The calorific values of the briquettes based on the ratios of waste paper and coffee residue.

From the results of the analysis of the fuel briquette properties shown in Table III, by using waste paper alone (100:0), it rendered the calorific value of 3,230 cal/g while using coffee residue alone (0:100) rendered the calorific value of $4,845 \mathrm{cal} / \mathrm{g}$. From the calorific values ranging between 3,200 cal/g and 4,845 cal/g (see Fig. 3), there was an upward trend in the calorific values. To make a comparison, the calorific value of firewood in general is 4,390 cal $/ \mathrm{g}$ ) [3], [4], sawdust (4820 cal/g) [5] and corncob (4,973 cal/g) [6], but wood charcoal generates the calorific value of 7,430 $\mathrm{cal} / \mathrm{g}$, which is much higher than that of the briquette. The contributing factor lies in the fact that wood charcoal is made through combustion and carbonization (the process of adding carbon), causing an increase in carbon content. Based on the study, the moisture content varied, depending on the amount of the coffee residue which fell in the range of $6.67 \%$ to $10.85 \%$ (by weight) while that of firewood is $8.0 \%$ and wood charcoal's is $9.4 \%$.

Based on the analysis derived from the results shown in Table III, it was discovered that amongst the nine ratios between waste paper and coffee residue, there were only five optimal ratios (by weight): $70: 30,60: 40,50: 50,40: 60,30$ $: 70$, which were measured in terms of ash content, volatile matter, fixed carbon, calorific value, and moisture content See Table IV.

TABLE IV: THE PHYSICO-CHEMICAL CHARACTERISTICS OF THE BRIQUETTES MADE FROM WASTE PAPER AND COFFEE RESIDUE

\begin{tabular}{cccccc}
\hline \hline Parameter & \multicolumn{5}{c}{ Waste paper : Coffee residue (by weight) } \\
\cline { 2 - 6 } & $70: 30$ & $60: 40$ & $50: 50$ & $40: 60$ & $30: 70$ \\
\hline $\begin{array}{c}\text { Ash content } \\
(\%)\end{array}$ & 8.50 & 7.26 & 6.14 & 4.64 & 3.86 \\
$\begin{array}{c}\text { Volatile } \\
\text { matter (\%) }\end{array}$ & 82.03 & 83.06 & 83.00 & 84.25 & 85.90 \\
$\begin{array}{c}\text { Fixed carbon } \\
(\%)\end{array}$ & 1.93 & 1.92 & 2.84 & 2.1 & 1.07 \\
$\begin{array}{c}\text { Moisture } \\
\text { content }(\%)\end{array}$ & 7.54 & 7.76 & 8.02 & 9.01 & 9.17 \\
\hline \hline
\end{tabular}

From Table IV, the study discovered that the optimal ratios between waste paper and coffee residue were $50: 50,40: 60$, and $30: 70$, rendering the ash contents in the range of $4-6 \%$, which were slightly higher than that of firewood (3.9\%), and lower than wood charcoal's (5.4\%), except at the ratio of 50 : 50. Their volatile matters were in the range of $82-86 \%$, their fixed carbon contents were in the range of $1-3 \%$, lower than firewood's: $22.8 \%$ and much lower than wood charcoal's: $84.6 \%$. See Table V.

TABLE V: THE COMPARISON OF FUEL PROPERTIES AMONGST THE BRIQUETTES, FIREWOOD AND CHARCOAL

\begin{tabular}{cccc}
\hline \hline Parameter & $\begin{array}{c}\text { waste paper/coffee } \\
\text { residue }\end{array}$ & firewood & $\begin{array}{c}\text { wood } \\
\text { charcoal }\end{array}$ \\
\hline Calorific value (cal/g) & $4000-4800$ & 4390 & 7430 \\
Moisture content $(\%)$ & $7-9$ & 8 & 9.4 \\
Ash content $(\%)$ & $3.8-8.5$ & 3.9 & 5.4 \\
Volatile matter $(\%)$ & $82-86$ & 65 & 2 \\
Fixed carbon $(\%)$ & $1-3$ & 22.8 & 84.6 \\
\hline \hline
\end{tabular}

\section{Ultimate Analysis}

Ultimate analysis is an approach to find the intrinsic elements of fuels: carbon, hydrogen, oxygen, nitrogen, sulfur, and so forth it is useful in determining the quantity of air required for combustion, the volume of combustible 
gases, and the composition of combustible gases [5]. As suggested by [7], [8], the composition of those elements in biomass has an impact on the characteristics of fuel combustion, as the total mass of a fuel declines during a volatile combustion phase when the ratio between hydrogen and carbon increases and to a lesser extent when the ratio between oxygen and carbon ratio rises. The amounts of nitrogen, sulfur, and chlorine determine the emission level of noxious gases. If the level is higher than the specified amount, it will affect the nature of a combustion reaction and the amount of gas, becoming air pollution [9]. The elements found in the briquettes $(70: 30)$ are considered acceptable under biomass standards, which were $45.56 \%$ carbon, $6.48 \%$ hydrogen, $45.41 \%$ oxygen, $0.75 \%$ nitrogen, and $0.08 \%$ sulfur. See Table VI.

TABLE VI: ULTIMATE ANALYSIS

\begin{tabular}{cccccc}
\hline \hline \multirow{2}{*}{ Element } & $\begin{array}{c}\text { Waste } \\
\text { paper } \\
100 \%\end{array}$ & $\begin{array}{c}\text { Coffee } \\
\text { residue } \\
100 \%\end{array}$ & $\begin{array}{c}\text { Waste paper : } \\
\text { Coffee 70:30 }\end{array}$ & $\begin{array}{c}\text { Sawdust } \\
\text { briquette } \\
\text { [5] }\end{array}$ & $\begin{array}{c}\text { Biomass } \\
\text { [8], [9] }\end{array}$ \\
\hline $\mathrm{C}$ & 36.97 & 49.24 & 45.56 & 53.07 & $30-60$ \\
\hline $\mathrm{H}$ & 5.31 & 6.98 & 6.48 & 4.1 & $5-6$ \\
\hline $\mathrm{O}$ & 48.1 & 41.38 & 45.41 & 39.6 & $30-40$ \\
\hline $\mathrm{N}$ & 0.05 & 2.39 & 0.75 & 0.302 & $<1$ \\
\hline $\mathrm{S}$ & 0.03 & 0.16 & 0.082 & 0.28 & $<1$ \\
\hline others & 9.54 & 6 & 0.778 & 2.65 & - \\
\hline \hline
\end{tabular}

\section{CONCLUSION}

Briquettes produced from waste paper and coffee residue could be an alternative to generate fuel for Thailand, as opposed to the uses of firewood and wood charcoal. The study discovered that the fuel briquettes had desirable characteristics to produce fuel for household since they were easily molded, inflammable with low amount of smoke. Their combustion levels were also in accordance with biomass standards (without causing air pollution) and their calorific values were similar to that of firewood, but not as high as wood charcoal's. Therefore, the briquette is suitable as a fuel for household activities (requiring moderate heating values), but not as efficient as wood charcoal for boiling and cooking. However, the production of the briquettes requires less energy resources as opposed to the production of wood charcoal, which requires a large amount of energy to burn wood before turning it into wood charcoal. In addition, the briquettes could also be made at home as their production involves a cold-pressed process, and briquette molders are available to purchase in many places (resulting in lower energy consumption and lower cost). All in all, briquettes produced in this study could be one of the viable fuel resources for our future thanks to their several benefits as discussed throughout this paper. Most importantly, they are environmentally friendly resources, which would benefit our society in the long run.

\section{ACKNOWLEDGMENT}

Special thanks goes to ILC (Innovative Learning Center) Srinakharinwirot University for financial support to this study and Scientific and Technological Research Equipment Centre Chulalongkorn University for giving us access to their analysis equipment and also helping with the laboratory work.

\section{REFERENCES}

[1] Reducing paper use and increase the use of waste paper from the office. (2012). The Management of Waste and Hazardous Substances. Ministry of Natural Resources and Environment. Ministry of Natural Resources and Environment. [Online]. Available: http//www.pcd.go.th/info_serv/waste_paper.html

[2] B. Nyer, "Fuel briquette materials assessment," Techno Serve Guatemala, University of Colorado Engineering for Developing Communities Program, March 25, 2012

[3] W. Satheinsawat, "Research on green fuel," M.S. thesis, Dept Horticulture, Kasetsart Univ., Bangkok, Thailand, 1986.

[4] Guidelines and eligibility of waste for processing into fuel rods and binder block, The Management of Waste and Hazardous Substances, 2012, p. 13

[5] J. O. Akowuah, F. Kemausuor, and S. J. Mitchual, "Physico-chemical characteristics and market potential of sawdust wood charcoal briquette," International Journal of Energy and Environmental Engineering, vol. 3, no. 20, 2012

[6] J. T. Oladeji, "Fuel characterization of briquettes produced from corncob and rice husk residues," Pac. J. Sci. Technol., vol. 11, no. 1, pp. 101-106, 2010.

[7] N. A. Musa, "Comparative fuel characterization of rice husk and groundnut shell briquettes," NJREDI, vol. 6, no. 4, pp. 23-27, 2007.

[8] P. D. Grover, S. K. Mishra, and J. S. Clancy, "Development of an appropriate biomass briquetting technology suitable for production and use in developing countries," Energy Sustain. Dev., vol. 1, no. 1, pp. $45-48,1994$

[9] J. Chaney, "Combustion characteristics of biomass briquettes," Ph.D. Dissertation, University of Nottingham, Nottingham, United Kingdom, 2010 .

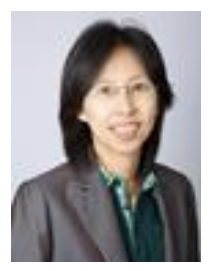

Patcharee Preedasuriyachai was born in Chiangmai, Thailand. In 2001, she received her bachelor of science degree in chemistry from Chiangmai University, Chiangmai, Thailand. She then completed her master of science degree in organic chemistry from Mahidol University, Bangkok, Thailand in 2005 and doctoral degree in petrochemistry from Chulalongkorn University, Bangkok, Thailand in 2012. She has served as a lecturer for the Innovative Learning Center at Srinakharinwirot University, Bangkok, Thailand for 2 years. Her research interests include but not limited to the recycle of wastes in community, alternative energy, organic chemistry and nanochemistry.

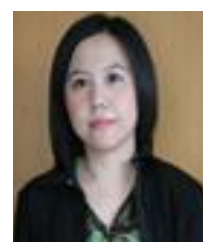

Naruephat Tangmankongworakoon was born in Nakhon Sawan, Thailand. In 1996, she received her bachelor of science degree in industrial chemistry from Chiangmai University, Chiangmai, Thailand. She then completed her master's and doctoral degrees in chemical technology from Chulalongkorn University, Bangkok, Thailand in 1999 and 2005

She has served as a lecturer for the Innovative Learning Center at Srinakharinwirot University, Bangkok, Thailand for 4 years. Her research interests include but not limited to the recycle of wastes in community, alternative energy, and the pyrolysis and kinetic model of unused waste. 


\section{Environmental Management}


